\title{
Financial Constraints and Investment: the Swiss Case
}

\author{
François-Serge Lhabitant* and Olivier Tingueli*
}

JEL classification: G32, G31

Keywords: financial constraints, investment, Tobin $Q$

\section{INTRODUCTION}

In their groundbreaking work, Modigliani and Miller (1958) showed that, in a perfect market, financial factors (e.g. cash flow) should not influence real investment decisions, and all cross-sectional variation in investment spending should be picked up by the expected profitability of these investments. Since then, many authors have shown that the predictions of the Modigliani and Miller theorem do not hold in an environment with taxes or in which there are information asymmetries between a firm's managers who have monopolistic access to information about the firm's expected cash flows, and outside investors who do not. The major conclusion to be taken from this literature is that, due to the presence of imperfect markets, firms face financial constraints, ${ }^{1}$ see e.g. GERTLER (1988) for a survey.

There is now an extensive body of literature examining the role of financial constraints in company investment decisions. In a seminal work, FAZARRI, HubBard and PETERSON (1988) demonstrated a significant correlation between investment and cash flow in the US and argued that the sensitivity of investment to cash flow provides a good measure of financial constraint. The intuition is that upward sloping cost of funds schedules prevent firms from reaching their optimal level of investment so that the internal cash generated by past investments, that is, the availability of financing, partly determines current investment spending. Similar empirical findings have been observed in other countries like the UK, Canada, France and Spain.

Union Bancaire Privée (Geneva), H.E.C. University of Lausanne and Thunderbird, The American Graduate School of International Management. E-mail: francois@lhabitant.net

CM Capital Markets (Madrid) and University Carlos III (Madrid).

The views expressed in this paper reflect purely the academic opinion of the authors. We thank Philippe Bacchetta, Shelley Collum, Jean-Pierre Danthine, Thomas Farmer, Jean Imbs, Frédéric Lobez, Franck Portier, Nils Tuchschmid, as well as participants at the AFFI Research Day (1999) and an anonymous referee for their helpful comments and suggestions.

1. By financial constraints, we mean that a firm is not able to fund all the projects it wants to. Such a situation might arise because of credit constraints, inability to borrow or to issue equity at a reasonable cost, low liquidity of assets or similar phenomena. 
The evaluation method proposed by FAzzARI et al. (1988) is based on data from a panel of firms and uses the following approach. First, a sample of firms is split according to an a priori specified criterion that is assumed to measure financial constraints. Next, investment levels of the firms are regressed on variables representing investment opportunities and cash flow. If firms that were a priori and exogenously defined as more constrained exhibit a stronger sensitivity to cash flow than the others, the authors conclude that these firms are effectively more constrained in financial markets.

In an important paper, KAPLAN and Zingales (1997) refuted the conclusions of this type of tests. Using a simple theoretical model, they showed that the link between the investment-cash flow sensitivities and the intensity of financial constraints was not necessarily monotonically increasing. Moreover, repeating the empirical exercise of FAZZARI et al. (1988) but using a different a priori criterion, KAPLAN and ZINGALES (1997) found that the a priori most financially constrained firms did not exhibit the highest investment-cash flow sensitivity.

The objective of the present paper is twofold: $i$ ) to analyze the role of financial constraints in company investment decisions for a different country, namely Switzerland; and ii) to improve the quality of the test. This second task is critical in order to assess the validity of the empirical results of KAPLAN and ZiNGALES (1997) and to determine if the theoretical possibility advanced by those authors is in fact empirically true. The empirical test is modified on four ways: $i$ ) the a priori criterion, ii) the possibility of a different behavior of investment-cash flow sensitivities over the business cycle, iii) the use of a dynamic rather than static classification strategy and $i v$ ) the estimation procedure. We develop below the three first points while leaving the last point for section 3.

\subsection{The a priori Criterion}

The first step of the method consists in choosing an a priori criterion to group firms according to their probability of being financially constrained. This step is crucial, as an inadequate grouping can lead to incorrect conclusions.

The ideal strategy would be to build a direct measure of financing constraints. Unfortunately, this seems to be a nearly impossible task. Most of the studies, including FAZZARI et al. (1988) and KAPLAN and ZINGALES (1997), classify firms according to criteria such as their dividend payout or dividend to sales ratio. The argument is that a firm without financial constraints can afford to pay high dividends without harming its investment level because it will be able to compensate its lower free cash flows with external financing. However, this criterion has been criticized because it is ambiguous: low dividends can indeed arise from financing constraints, but also from a dividend clientele effect, or to avoid undesirable signaling; see for instance DeNIS et al. (1994). Other sorting criteria are also found in the literature: small versus large, young versus old, group versus nongroup members, or low rates of return (ROR) versus high ROR companies, etc. They 
are also subject to criticism; see KadapaKкам et al. (1998), Vogt (1994), Hoshi et al. (1991), or KATHuria and Mueller (1995).

In this paper, we do not use such criteria to discriminate among firms, but attempt to reverse the causality. Since financial constraints on investment may be an unavoidable consequence of asymmetric information between investors and firms, we focus directly on asymmetric information indicators. ${ }^{2}$ The more a firm is subject to asymmetric information between insiders in the firm and potential outside investors, the more constrained it will be on financial markets, the link between them being monotonically increasing.

This approach allows us to bypass the criticism of non-unique interpretation and is consistent with a large line of theoretical reasoning. Indeed, many researchers have hypothesized asymmetric information as the culprit of under-investment; see for instance, Myers and Majluf (1984) or Stiglitz and Weiss (1981). In addition, since Swiss capital markets are free of state controls, financial constraints, if any, should essentially result from asymmetric information. ${ }^{3}$ Therefore, the more asymmetric information a firm experiences, the more financially constrained it should be.

\subsection{The Business Cycle}

As stressed in the literature, the intensity of financial constraints is not constant over time, and firms are heterogeneously affected by financial constraints; see for example Bernanke et al. (1996). During a boom, firms with more asymmetric information may have similar access to external financial markets as firms with less asymmetric information. But in bad times, financial constraints should be more binding for firms with a stronger asymmetry of information. This results in cyclical financial constraints over time and non-constant investment cash-flow sensitivities.

If we do not take into account the business cycle in the estimation, the estimated investment cash-flow sensitivities for constrained firms will be a weighted-average of the boom period (in which coefficients are homogeneous) and of the recession period (in which coefficients are heterogeneous). Therefore, the heterogeneity among firms will artificially decrease and this may lead to a rejection of the presence of financial constraints even if they exist. If the business cycle is taken into account, the result of the estimation won't be subject to this problem. We therefore split the sample into a boom and a recession period.

2. In Section 2, the types of information asymmetries we use are discussed more in depth.

3. Although tax distortions could lead to the same result, it is hard to believe that they would significantly affect financing constraints. 


\subsection{Our Dynamic Classification Strategy}

Furthermore, our classification of firms among group is dynamic, which is in contrast with the existing literature. Most of the authors classify firms in the same group during the whole observation period based on a single criterion, such as the average or terminal dividend payout. Consequently, firms do not change groups and the threshold separation between the groups is rather subjective.

By contrast, we allow for firms to change groups within the observation period on a yearly basis. In particular, for a given year, we assign a firm to a group if it fulfilled the criteria defining the group in the previous year. As an illustration, consider the following situation. Suppose that a firm modifies its capital structure and that this leads to a reduction of information asymmetry. As we use asymmetric information indicators to differentiate firms, this firm should exhibit the same investment-cash flow sensitivity as a firm that is less likely to be financially constrained. The adjustment speed between the two states should be fast, because capital structure changes are public information. To take this into account, the firm classification is modified for the next period, that is, the following year.

Having established the specificities of our approach, we now turn our attention to other matters. Section 2 describes the Swiss market and the asymmetries of information that arise from its idiosyncrasies. Section 3 presents the econometric tests. Section 4 describes the sample. In Section 5, the results and the major findings are summarized. Section 6 concludes the paper and suggests some paths for further research.

\section{THE SWISS MARKET}

As mentioned in Section 1.1, the key step in our approach is the identification of an appropriate sorting criterion. We particularly focus on several sources of informationdriven imperfections in the Swiss financial market. These information asymmetries stem from the ownership structure of Swiss corporations typified by dual-class shares, and the role of banks as equity owners and proxy voters.

\subsection{Ownership Structure and dual class shares}

An interesting feature of the Swiss Market is the high degree of ownership concentration, combined frequently with a dual-class share structure.

Smaller Swiss firms often have shareholders - typically founding families or their descendants - that still own a significant portion of the firm's equity. As shown by JENSEN and Meckling (1976), the presence of concentrated ownership can be beneficial for all stakeholders, because it eases the job of monitoring and directing corporate management. This is the case in Switzerland, where the concentration of ownership is often 
combined with a high level of involvement of the major shareholders in the management of the firm. Although some regard significant share ownership by corporate insiders as a sign of commitment, it also results in an important information asymmetry between the controlling shareholders and the other claim holders, e.g. minority shareholders and creditors. This leads to important agency problems, because the controlling shareholders are in a position to maximize their own welfare and extract private benefits. In extreme cases, concentrated shareholding may lead to a situation where decisions are made to benefit the large shareholder at the expense of smaller ones; see e.g. STulz (2000). In addition, family and individual owners, while they may reap some benefits from close control over management, frequently lack monitoring expertise and are subject to the problem of generational change. As a consequence, firms with a concentrated ownership structure may experience greater financial constraints when looking for external financing.

In contrast, medium and large-size publicly traded Swiss firms are widely held corporations. However, in many cases their dispersed ownership structure does not disperse controlling authority. A dual class share structure, which concentrates voting authority in a few shareholders' hands, sometimes gives a few shareholders control of the company without even owning a majority of equity.

Under Swiss Law, each share should be entitled to exactly one vote. However, it is possible to issue shares at differing par values. For example, 10 shares issued at a par value of 1 Swiss franc each will give ten times the voting rights of 1 share issued at a par value of 10 Swiss francs. Therefore, several Swiss firms have structured their capital using registered shares with a lower face value than bearer shares, giving registered shares investors more voting rights for an equal investment and an equal stake in the firm's cash flows. In addition, firms have also restricted the transferability of registered shares and limited in their articles the number of votes that one shareholder may cast in the shareholders' meeting. ${ }^{4}$ The major consequence of these policies has been the creation of a substantial liquidity gap in the stock market. Typically, firms have issued both types of shares but only the bearer ones are listed and frequently traded, while a small group of investors controls the issuing firm by holding the registered shares, which are not frequently traded or even not traded at all. The only public information about these registered shares is their nominal price, which is absolutely unrelated to their market value. $^{5}$

4. For instance, Nestle originally provided in its articles of association that: (i) the board of directors could refuse to register a shareholder without stating any reasons; (ii) the board of directors had the right to refuse registration of a shareholder who, directly or indirectly, held more than three per cent of the registered share capital; (iii) foreigners were only permitted to purchase bearer shares. Subsequently, Nestle was the first company that abolished bearer shares and allowed foreign investors to acquire its registered shares, with dramatic consequences for the price of its bearer shares; see LODERER and JACOBS (1995) or STULZ and WASSERFALLEN (1995) for a review.

5. See Horner (1988). For instance, on May 12, 1998, the Richemont bearer share had a nominal price of $100 \mathrm{CHF}$ and a traded price of $2092 \mathrm{CHF}$, while the Richemont registered share had a nominal price of $10 \mathrm{CHF}$ and was not traded. 
According to LA PORTA et al. (1999), about 36.7 percent of the large and medium publicly traded firms in Switzerland are ultimately controlled by a family or an individual Often, the holders of registered shares play an active role in the management of the firm and sit on the board of directors. This gives them access to private information about the firm's creditworthiness and about relevant features of its investment projects that is not readily available to outsiders, creating an asymmetry of information with respect to other claimholders. This asymmetry of information arises from two sources, namely, hidden information and the possibility of hidden actions, including insider trading ${ }^{6}$ and/or expropriation of other claimholders; see SHLEIfER and VISHNY (1997). The large shareholder may prefer to focus on generating private benefits even though he could increase substantially the value of the firm through his actions. The reason is that he gets all the private benefits, ${ }^{7}$ while he needs to share the profits of the value-increasing actions he takes. Therefore, issuing equity (bearer shares) or debt should be more costly for such firms because these instruments are sold to informed actors, as shown by MYERs and MAJLUF (1984). Of course, firms that have frequently-traded registered shares or have issued only bearer shares should not suffer from this informational problem.

These particularities of the Swiss market enable us to separate firms into two groups. The first group contains firms that trade their registered shares and the second firms that do not. However, to verify the robustness of this specification with respect to other aspects than trading, we also use two alternative classification schemes.

In the previous classification scheme, firms that do not trade their registered shares were considered as owned by a majority shareholder. To verify that potential differences in investment-cash flow sensitivities do not come from control related issues, we also split the sample into two groups: firms that are owned by a major shareholder (or a small group of investors) and firms that are not. This should show potential differences between control related issues and trading related issues. When a small group of investors own the firm, they have access to private information. When registered shares are frequently traded, this private information becomes public and the asymmetry of information should be reduced, so that the corresponding firms should exhibit similar investment-cash flow sensitivities.

Finally, we split our sample into three groups. The first group consists of firms that have publicly traded registered shares and have no major shareholder; in the second, we find firms with publicly traded registered shares with a major shareholder; in the last group, we have firms with non-traded registered shares. The differentiation of the groups should indicate the source of information asymmetry (the ownership structure and/or the trading of all shares) that has the largest influence on investment-cash flow sensitivities.

6. Even if informed investors start trading bearer shares, information is not immediately reflected in their price, because the bearer shares market is by definition anonymous (the investor's identity is not known by market participants).

7. BARCLAY and HoldERNESS (1989) show that these benefits can be considerable even in the U.S. ZINGALES (1994) provides evidence that these benefits are extremely large in Italy. 


\subsection{The Role of Banks}

Another interesting feature of the Swiss business environment is the important role played by banks in corporate governance. Unlike the US, Switzerland allows its banks to own controlling stakes in industrial firms and act as active investors. As a result, Swiss banks tend to hold considerable equity portfolios themselves, often name representatives to the firms' boards and exercise considerable influence and control in the company with which they have a relation. This is often justified as a means to support medium sized companies that are weakly endowed with capital, to provide credit access to enterprises which get into liquidity difficulties, as an anti take-over measure or as a long-term investment. In addition, a side effect of retail brokerage and private banking is that many customers keep their shares at the bank without giving special instructions. Banks will use the corresponding voting rights, which will provide them with additional if not total - control at annual meetings. A similar "bank-based" environment exists in Germany and Japan, in contrast with the Anglo-American "market-based" system; see for instance GorTon and Schmid (1996) and Hoshi et al. (1991).

What is the impact of a "bank-based" environment on financial constraints? On the one hand, as demonstrated by ADmaTi et al. (1994), the simultaneous ownership of both debt and equity claims by banks can be beneficial for the firm if this alleviates potential conflicts of interests between creditors and equity holders, such as the under-investment, asset-substitution, and over-investment problems. ${ }^{8}$ Instead of arm's length lenders, banks tend to have more complex and longer-term relations with corporate clients. The close relation between a bank and its client firms provides banks greater access to firm-specific information and easier monitoring. This reduces asymmetric information problems, enabling banks to supply more financing to firms at a lower cost (lower risk premiums), and thus increasing investment efficiency. ${ }^{9}$ Banks may also play a certification role on the board, signalling firms' creditworthiness to other investors, and also delivering capital to firms facing liquidity shortfalls, thereby avoiding costly financial distress; see SchwiETE and WeIgand (1997). Therefore, firms with a controlling and monitoring bank should experience lower financial constraints, as evidenced by HosHI et al (1990).

To take this into account, we separate our firms into two groups based on whether or not they have a bank as an important shareholder. By "important", we mean a bank owning at least $10 \%$ of the capital of a firm. Note that we do not use board representation of banks as a criterion because the power that comes from board representation is in a sense "derived" from equity control rights.

8. See for instance Myers (1977), Jensen and Meckling (1976), Stulz (1990), Dewatripont and TIROLE (1994) and RAJAN (1992).

9. Greenbaum et al. (I 1989), Sharpe (I990) and Rajan (1992) study some of the implications of the information advantage gained by the bank in its relationship with a firm. For example, BERGER and UDELL (1995) find that borrowers with longer banking relationships obtain better financing conditions in terms of both collateral and interest rates. 


\subsection{A Note on the Evolution of the Swiss Market}

Another characteristic of the Swiss market is the important structural changes that have occurred since the beginning of the nineties. The Swiss economy was then hit by a strong recession, which worsened the financial position of several firms. It has often been argued that, since 1990, access to external financing has been reduced because banks apply more restrictive conditions for their corporate loans. These tougher economic and financial conditions have also led firms to modify their ownership structure. First, many firms have opened their registered capital to the public and have progressively eliminated the differences between bearer and registered shares by trading both or by converting them into a single type. Second, bankruptcies have greatly increased the number of firms with an important bank shareholder. In our sample, over the total period, the number of firms that do not trade their registered shares has decreased by one third and the number of firms with an important bank shareholder has doubled. Fortunately, thanks to our dynamic classification approach (see Section 1.3), we are able to account for these changes and sort Swiss firms accordingly.

\section{THE ECONOMETRIC EXPERIMENT}

\subsection{The Econometric Specification}

We follow the method introduced by FAzZari et al. (1988). First firms are split into groups according to the a priori criteria. Then, for each sampling division, we estimate the coefficients of the following equation:

$$
\left(\frac{I}{K}\right)_{i, t}=\delta_{i}+\alpha_{t}+\beta_{j} \cdot Q_{i, t}+\varepsilon_{i, t}
$$

where $\delta$ is a fixed effect dummy and $\alpha$ is a time dummy, $\beta$ is the regression coefficient and $\varepsilon$ is a stochastic error term; $i, j$ and $t$ are indexes for, respectively, firms, groups of firms, and time; $I, K$ and $Q$ represent, respectively, investment, capital and marginal Tobin's $Q$.

Equation (1) represents the neoclassical investment theory in the presence of convex adjustment costs where the marginal $Q$ is the only pertinent variable explaining investment decisions. ${ }^{10}$ Marginal $Q$ is defined as the ratio between the marginal productivity of one unit of investment and the replacement cost of capital. 
Then, we estimate the coefficients of a second equation with cash flow (CF):

$$
\left(\frac{I}{K}\right)_{i, t}=\delta_{i}+\alpha_{t}+\beta_{j} \cdot Q_{i, t}+\gamma_{j} \cdot\left(\frac{C F}{K}\right)_{i, t}+\varepsilon_{i, t}
$$

where the new variable $\gamma$ is the regression coefficient.

Cash flow measures the availability of internal funds. In a world where the Modigliani-Miller theorem holds, the coefficient should be equal to zero. If it is significantly positive, financing issues matter, and therefore, financial constraints may exist.

Finally, we compare the value of the coefficients that we obtained among the various groups and see if we can draw a conclusion such as "the higher the cash flow coefficients, the tighter the financial constraints". As already mentioned, KaPLAN and Zingales (1997) criticized this conclusion for having no theoretical support.

\subsection{Estimation Method and Related Issues}

As the marginal $Q$ is not observable, we use as a proxy the average $Q$. The latter is defined as the ratio between the market value of the outstanding financial claims on the firm and the current replacement cost of firm assets. Following the literature, to take into account the measurement error, we use instrumental variable estimators with one period lagged average $Q$ as instruments.

To study the issue of the business cycle, we first estimate the coefficients of equations (1) and (2) using a time dummy variable for each year $\left(\alpha_{t}\right)$. Then, the sample is split into two periods: a boom period and a recession period. In this case the time dummies are suppressed which allows us to examine the behavior of investment-cash flow sensitivities over the two periods.

The sample is made up of firms with different sizes and which come from different economic sectors. To avoid biases due to company size, investment and cash flow are divided by capital. As firms come from different sectors, they probably have different investment propensities. Consequently, the equations are estimated through weighted least squares to correct for heteroskedasticity.

The estimation is simultaneously performed for all groups and for the whole period. This procedure is in contrast to the literature in which an equation is estimated for each group. The advantage of this procedure lies in the possibility of statistically testing differences among groups. A major shortcoming in FAzZARI et al. (1988) and KAPLAN and ZINGALES (1997) is that differences cannot be tested. Therefore, with their model if firms exhibit different investment-cash flow sensitivities, nothing guarantees that those differences really exist and this may lead to erroneous conclusions.

Estimating equation (1) tests the reliability of Tobin's $Q$ theory of investment for Switzerland. If the predicting power of this equation is not sufficient, i.e. the $R^{2}$ is low, the interpretation of the inclusion of cash flow will not be clear. In that case, one can al- 
ways argue that cash flow is only a proxy for the marginal $Q$ and has nothing to do with the cost of internal versus external financing.

\section{THE SAMPLE}

The sample starts in January 1984 and ends in December 1996. It consists of 58 firms whose shares (registered and/or bearer) are traded on the Swiss stock exchange (see Ap. pendix A). Firms whose activity belongs entirely to the financial sector, i.e. banks and insurance companies, are excluded from the sample. The list of firms and their classification is presented in appendix A. Firms that disappeared, were created or merged during the observation period are only considered over the period in which they existed as separate legal entities. In addition, before the corporate law revision of 1992, Swiss firms were not legally obliged to publish detailed accounts. Therefore, collecting data is a difficult task, and some firms are only considered during the time for which we could collect relevant information. We use three different sources of information: UBS Annual Swiss Stock Guides, Datastream International and the annual reports of firms.

Table 1: Descriptive Statistics for our sample

\begin{tabular}{|c|c|c|c|c|c|c|}
\hline & \multicolumn{6}{|c|}{ Whole Sample } \\
\hline & $\mathbf{I} / \mathbf{K}$ & $\mathbf{Q}$ & CF/K & & & \\
\hline Mean & 0.107 & 1.427 & 0.111 & & & \\
\hline Median & 0.067 & 1.030 & 0.093 & & & \\
\hline \multirow[t]{4}{*}{ Std. Dev. } & 0.345 & 1.679 & 0.108 & & & \\
\hline & \multicolumn{6}{|c|}{ Split Sample } \\
\hline & \multicolumn{3}{|c|}{ 1984-1989 } & \multicolumn{3}{|c|}{ 1990-1996 } \\
\hline & $\mathbf{I} / \mathbf{K}$ & $\mathbf{Q}$ & CF/K & $\mathbf{I} / \mathbf{K}$ & $\mathbf{Q}$ & $\mathrm{CF} / \mathrm{K}$ \\
\hline Mean & 0.142 & 1.831 & 0.134 & 0.085 & 1.258 & 0.105 \\
\hline Median & 0.068 & 1.063 & 0.096 & 0.065 & 1.051 & 0.095 \\
\hline Std. Dev. & 0.253 & 2.502 & 0.127 & 0.355 & 0.834 & 0.101 \\
\hline
\end{tabular}

Note: I, K, Q, CF represent respectively investment, capital, Tobin's $Q$ and cash flow.

Table 1 presents basic statistics. The technical details of their computation are given in the appendix. These statistics are in accord with those of similar studies like Hoshi et al. (1991). Nevertheless, they display some interesting characteristics.

The average investment-to-capital ratio (0.07) is low in comparison to other studies. In the US, FAZZARI et al. (1988) and CHIRINKo and SCHALlER (1995) obtained ratios of about 0.25. In Japan, Hoshi et al. (1991) reported a median value of 0.13 . This is lower than in the US, but still higher than in Switzerland. An overestimation of the replacement cost of capital (see Appendix B) does not seem to be an explanation, because 
other ratios are similar. In contrast, the standard deviation of the investment-to-capital ratio is high. This is a result of the fact that the sample is composed of firms belonging to different economic sectors, with differing investment levels among firms and different reporting standards.

Tobin's $Q$ exhibits an average of 1.43 , which may appear as being high. However, the lower bound of Tobin's $Q$ is zero and there is no upper bound. Consequently, an average above one is expected. This is confirmed by the median, which is close to one. Here again, the standard deviation suggests a strong heterogeneity among firms and/or the presence of outliers.

When splitting the sample, all coefficients are lower in the second period. The average investment-to-capital ratio decreases from 0.14 to 0.09 . This observation captures the effect of the business cycle on investment. It is a well-known fact that investment is much more volatile than output over the business cycle, while aggregate capital is not. For example, in the US, the standard deviation of the level of investment is about four times higher than the standard deviation of output level. In the case of Tobin's $Q$, the median and the mean both decrease in the second period. On the one hand, this is an indication that investment became less profitable, and should partially explain the decrease of the investment-to-capital ratio. On the other hand, average cash flow also slightly decreases, as the financial situation of firms worsened. The decrease of both Tobin's $Q$ and cash flow imply a decrease in investment during the second period.

Table 2: Correlation coefficients between variables

\begin{tabular}{|c|c|c|c|c|c|c|}
\hline & \multicolumn{6}{|c|}{ Whole Sample } \\
\hline & $\mathbf{I} / \mathbf{K}$ & $\mathbf{Q}$ & CF/K & & & \\
\hline $\mathbf{I} / \mathbf{K}$ & 1.00 & 0.23 & 0.22 & & & \\
\hline $\mathbf{Q}$ & 0.23 & 1.00 & 0.70 & & & \\
\hline \multirow[t]{4}{*}{ CF/K } & 0.22 & 0.70 & 1.00 & & & \\
\hline & \multicolumn{6}{|c|}{ Split Sample } \\
\hline & \multicolumn{3}{|c|}{ 1984-1989 } & \multicolumn{3}{|c|}{ 1990-1996 } \\
\hline & $\mathbf{I} / \mathbf{K}$ & $\mathbf{Q}$ & CF/K & $\mathbf{I} / \mathbf{K}$ & $\mathbf{Q}$ & $\mathrm{CF} / \mathrm{K}$ \\
\hline $\mathbf{I} / \mathbf{K}$ & 1.00 & 0.46 & 0.42 & 1.00 & 0.08 & 0.16 \\
\hline $\mathbf{Q}$ & 0.46 & 1.00 & 0.80 & 0.08 & 1.00 & 0.60 \\
\hline CF/K & 0.42 & 0.80 & 1.00 & 0.16 & 0.60 & 1.00 \\
\hline
\end{tabular}

Note: I, K, Q, CF represent respectively investment, capital, Tobin's Q and cash flow.

Table 2 presents the correlation coefficients between variables. The low correlation of investment with other variables suggests the need for multiple factors to explain investment behavior. It indicates that Tobin's $Q$ is not a sufficient statistic to determine investment in contrast to the predictions of the Modigliani-Miller theorem. 
All correlations with investment decrease in the second period. The highest decrease is observed between investment and Tobin's $Q$. In particular, investment is more correlated with Tobin's $Q$ than with cash flow in the first period, while the opposite occurs in the second. This suggests that return considerations become less important in determining investment levels while financial issues may play a more important role in the second sub-period.

Cash flow is correlated with Tobin's $Q$. This is because these two variables provide similar information. If the correlation coefficient was moderate, both variables would carry their own information and correlation would not be a severe problem. Unfortunately, in the first period, the correlation between Tobin's $Q$ and cash flow reaches 0.8 . Therefore, it may not be possible to differentiate between the effect of Tobin's $Q$ and the effect of cash flow or, in other words, it may be impossible to differentiate between return and financial considerations.

\section{EMPIRICAL RESULTS}

\subsection{Ownership Structure}

\subsubsection{Dual Class Shares}

We first split firms between those whose stocks are all traded (group 1) and those where this is not the case (group 2). Results are presented in Table 3. We do not report coefficient of dummy variables because they do not provide pertinent information.

Both groups have similar investment and cash flow statistics, but different $Q$ patterns. All figures are higher in group 2 than in group 1 . The high values of the mean and standard deviation of Tobin's $Q$ in group 2 is explained by the presence of some outliers, due to the necessary estimation of the market value of their (non-traded) shares. However, the medians for group 2 and group 1 firms remain close. Accordingly, the estimation of Tobin's $Q$ seems to be trustworthy.

With an adjusted $R$-square ranging between 0.81 and 0.83 , the regression analysis provides a remarkable fit compared to similar studies, even when Tobin's $Q$ is the only explanatory variable. The inclusion of cash flow explains the situation better but only slightly. In all the equations, the coefficients of Tobin's $Q$ are significantly different from zero. Thus, the average $Q$ carries important information to explain investment decisions, and it may represent a good proxy for investment opportunities.

When the sample is split, in the first period, our results are similar to KaPLAN and Zingales (1997). Tobin's $Q$ does not carry any information and cash flow is then the unique variable explaining investment, with homogeneous coefficients $\left(\gamma_{1}>\gamma_{2}\right.$, but the difference is not statistically significant). On the other hand, the $\gamma$ coefficient differs across the two samples in the second period $\left(\gamma_{1}<\gamma_{2}\right.$, significant). This is consistent with the hypothesis that financial constraints are more binding in recessions than 
in good times. Surprisingly, the cash flow coefficients are higher in the first period than in the second. But since in the first period, the coefficients of Tobin's $Q$ are not significant, cash flow captures both investment opportunities and financial considerations.

Table 3: Impact of ownership structure

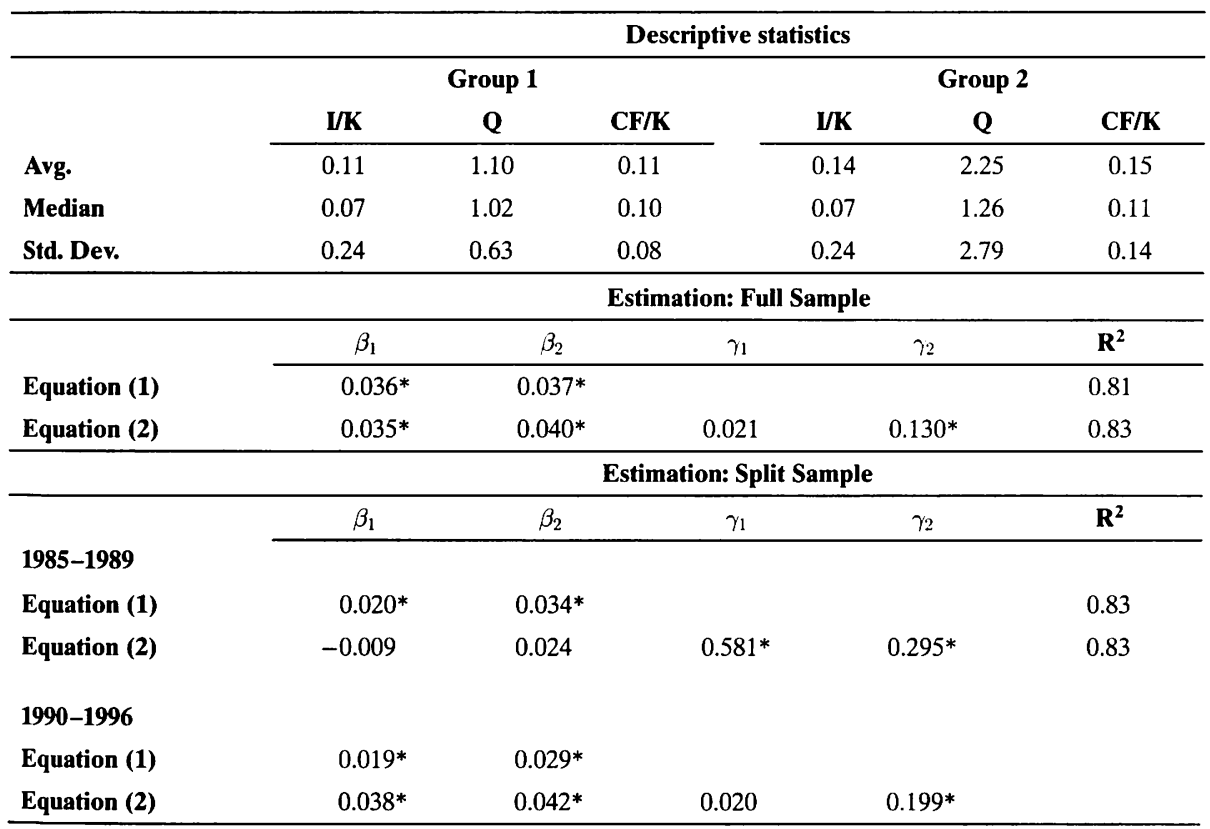

Notes: Firms are first separated between those that trade all their stocks (group 1, 38 firms) and those that do not (group 2, 14 firms), with 6 firms changing group over the sample period. Avg., Med., Std. denote, respectively, average, median and standard deviation. $\mathbf{R}^{2}$ stands for adjusted $\mathrm{R}$-square. A star $\left.{ }^{*}\right)$ denotes statistical significance at the $5 \%$ level.

\subsubsection{Major Shareholder}

To check the robustness of the previous specification, we repeated the analysis differentiating firms according to the absence (group 1) or presence (group 2) of a major shareholder. This allows us to verify if the control of a firm influences the investment-cash flow sensitivities. The results are presented in Table 4. 
Table 4: Impact of ownership structure

\begin{tabular}{|c|c|c|c|c|c|c|}
\hline & \multicolumn{6}{|c|}{ Descriptive statistics } \\
\hline & \multicolumn{3}{|c|}{ Group 1} & \multicolumn{3}{|c|}{ Group 2} \\
\hline & $\mathbf{I} / \mathbf{K}$ & $\mathbf{Q}$ & & $\mathbf{I} / \mathbf{K}$ & $\mathbf{Q}$ & $\mathbf{C F} / \mathrm{K}$ \\
\hline Avg. & 0.08 & 1.04 & & 0.15 & 1.76 & 0.14 \\
\hline Median & 0.06 & 0.84 & & 0.07 & 1.15 & 0.11 \\
\hline \multirow[t]{3}{*}{ Std. Dev. } & 0.05 & 0.68 & & 0.31 & 2.13 & 0.12 \\
\hline & \multicolumn{6}{|c|}{ Estimation: Full Sample } \\
\hline & $\beta_{1}$ & $\beta_{2}$ & $\gamma_{1}$ & & $\gamma_{2}$ & $\mathbf{R}^{2}$ \\
\hline Equation (1) & $0.041^{*}$ & $0.034^{*}$ & & & & 0.75 \\
\hline \multirow[t]{3}{*}{ Equation (2) } & $0.034^{*}$ & 0.013 & 0.036 & & $0.179 *$ & 0.98 \\
\hline & \multicolumn{6}{|c|}{ Estimation: Split Sample } \\
\hline & $\beta_{1}$ & $\beta_{2}$ & $\gamma_{1}$ & & $\gamma_{2}$ & $\mathbf{R}^{2}$ \\
\hline \multicolumn{7}{|l|}{ 1985-1989 } \\
\hline Equation (1) & $0.035^{*}$ & $0.037^{*}$ & & & & 0.76 \\
\hline Equation (2) & 0.031 & $0.028^{*}$ & 0.230 & & 0.171 & 0.83 \\
\hline \multicolumn{7}{|l|}{ 1990-1996 } \\
\hline Equation (1) & $0.042^{*}$ & $0.028^{*}$ & & & & \\
\hline Equation (2) & $0.055^{*}$ & $0.030^{*}$ & $0.029 *$ & & $0.139 *$ & \\
\hline
\end{tabular}

Notes: Firms are first separated between those that have no major shareholder (group 1, 23 firms) and those that have one (group 2, 29 firms), with 6 firms changing groups over the sample period. Avg., Med., Std. denote, respectively, average, median and standard deviation. $\mathrm{R}^{2}$ stands for adjusted $\mathrm{R}$ square. A star $\left(^{*}\right)$ denotes statistical significance at the $5 \%$ level.

When the full sample is used, investment level is not sensitive to cash flow in group 1 firms, while it is in group 2 firms. Unfortunately, Tobin's $Q$ coefficient of group 2 firms is not significantly different from zero in equation 2. Therefore, РотERBA's (1988) remark applies ${ }^{11}$ and no robust conclusion can be drawn.

When the sample is split into two periods, results are similar to those obtained with the previous classification scheme. In the first period, both groups have similar cash flow sensitivities $\left(\gamma_{1}>\gamma_{2}\right.$, but their difference is not significant and none of the coefficients is significantly different from zero). Tobin's $Q$ coefficient remains significant for

11. Poterba (1988), in a comment on Fazzari et al. (1988), identified the following problem. Assume that firms are split into two groups, investment is regressed first on investment and then on investment and cash flow (cash flow coefficients differ among groups). In this case, firms seem to be heterogeneously affected by financial constraints. Nevertheless, this is not necessarily true. The inclusion of cash flow naturally modifies the estimated coefficient value of Tobin's $Q$ between the two equations. If the value of this coefficient falls much more in one group than in the other, a higher coefficient of cash flow does not necessarily imply tighter financial constraints. In this case, cash flow in the group in which the fall of the estimated coefficient value of Tobin's $Q$ is more important can only be a better proxy for investment opportunities. 
group 2 firms but not for group 1 firms. This indicates that cash flow does not play an important role in this period. It also suggests that, in the previous estimation, cash flow was significant only because Tobin's $Q$ was not. In other words, cash flow was a better proxy for investment opportunities, because firms were exhibiting a different sensitivity to Tobin's $Q$ and a similar sensitivity to cash flow. This problem may be due to a misclassification of firms among the groups. Therefore, in Table 3, we should be aware that cash flow might not represent financing constraints.

\subsubsection{Non-Trading Issues vs. Major Shareholder}

We now distinguish between control-related effects and non-trading issues. group 1 contains firms with no major shareholder, group 2 firms with a major shareholder and traded registered shares, and group 3 firms with a major shareholder and non-traded registered shares. group 3 clearly contains the most likely to be financially constrained firms. Results are presented in Table 5.

Table 5: Impact of ownership structure

\begin{tabular}{|c|c|c|c|c|c|c|c|c|c|}
\hline & \multicolumn{9}{|c|}{ Descriptive Statistics } \\
\hline & \multicolumn{3}{|c|}{ Group 1} & \multicolumn{3}{|c|}{ Group 2} & \multicolumn{3}{|c|}{ Group 3} \\
\hline & $\mathbf{I} / \mathbf{K}$ & $\mathbf{Q}$ & $\mathrm{CF} / \mathrm{K}$ & $\mathbf{~} / \mathbf{K}$ & $\mathbf{Q}$ & $\mathbf{C F} / \mathrm{K}$ & $\mathbf{I} / \mathbf{K}$ & $\mathbf{Q}$ & $\mathrm{CF} / \mathrm{K}$ \\
\hline Avg. & 0.08 & 1.04 & 0.10 & 0.16 & 1.32 & 0.13 & 0.14 & 2.25 & 0.15 \\
\hline Median & 0.06 & 0.84 & 0.08 & 0.0 & 1.14 & 0.12 & 0.07 & 1.26 & 0.11 \\
\hline Std. Dev. & 0.05 & 0.68 & 0.07 & 0.3 & 0.79 & 0.09 & 0.24 & 2.79 & 0.14 \\
\hline
\end{tabular}

Estimation: Full Sample

\begin{tabular}{|c|c|c|c|c|c|c|c|}
\hline & $\beta_{1}$ & $\beta_{2}$ & $\beta_{3}$ & $\gamma_{1}$ & $\gamma_{2}$ & $\gamma_{3}$ & $\mathbf{R}^{2}$ \\
\hline Eq. (1) & $0.042^{*}$ & $0.034^{*}$ & $0.034^{*}$ & & & & 0.79 \\
\hline Eq. (2) & $0.035^{*}$ & $0.027^{*}$ & $0.020^{*}$ & 0.038 & 0.053 & $0.163^{*}$ & 0.89 \\
\hline
\end{tabular}

Estimation: Split Sample

\begin{tabular}{|c|c|c|c|c|c|c|c|}
\hline \multirow[b]{2}{*}{$1985-198$} & $\beta_{1}$ & $\beta_{2}$ & $\beta_{3}$ & $\gamma_{1}$ & $\gamma_{2}$ & $\gamma_{3}$ & $\mathbf{R}^{2}$ \\
\hline & & & & & & & \\
\hline Eq. (1) & $0.046^{*}$ & $0.042^{*}$ & $0.041^{*}$ & & & & 0.76 \\
\hline Eq. (2) & 0.022 & 0.012 & $0.035^{*}$ & 0.266 & 0.379 & 0.177 & 0.82 \\
\hline
\end{tabular}

1990-1996

\begin{tabular}{lllllll} 
Eq. (1) & $0.053^{*}$ & $0.032^{*}$ & $0.034^{*}$ & & & \\
Eq. (2) & $0.052^{*}$ & 0.009 & $0.047^{*}$ & $0.030^{*}$ & 0.293 & $0.201 *$ \\
\hline
\end{tabular}

Notes: Firms are first separated between those that have no major shareholder and trade all their shares (group 1, 24 firms), those that have a major shareholder and trade all their shares (group 2, 11 firms), and those who have a major shareholder and do not trade all their shares (group 3, 14 firms), with 9 firms changing groups over the sample period. Avg., Med., Std. denote, respectively, average, median and standard deviation. $\mathrm{R}^{2}$ stands for adjusted $\mathrm{R}$-square. A star $\left({ }^{*}\right)$ denotes statistical significance at the $5 \%$ level. 
In the full sample, results are similar to FAZZARI et al. (1988), i.e. a monotonic increasing function which links investment-cash flow sensitivities and the intensity of financing constraints. In the first two groups, firms have similar cash flow coefficients $\left(\gamma_{1}<\gamma_{2}\right.$, but the difference is not significant). Likewise, firms of the third group exhibit a significantly higher cash flow coefficient. This result is robust, because all Tobin's $Q$ coefficients are significant.

When the sample is split, in the boom period, investment level is not sensitive to cash flow. Nevertheless, cash flow coefficients exhibit a behavior similar to the one found by KAPLAN and Zingales (1997). Group 3 firms have the lowest cash flow coefficient but also the only significant Tobin's $Q$ coefficient. Thus the estimated cash flow coefficient for group 1 and group 2 firms has a high value only because it represents both return and financial issues. Consequently, no conclusion can be drawn as to the possible presence of financial constraints.

In the second period, the function linking the investment-cash flow sensitivities and the intensity of financial constraints seems to be monotonically increasing. When Tobin's $Q$ coefficients are significant, less likely to be financially constrained firms have a lower cash flow coefficient than more likely to be financially constrained firms. Although these results suffer from the non-significance of Tobin's $Q$ coefficients in group 2 in most of the equations, given our previous estimations, it is hard to resist again the conclusion that higher cash flow-investment sensitivities indicate stronger financial constraints.

\subsection{Banking Shareholders}

We split firms according to the absence (group 1) or presence (group 2) of an important banking shareholder. In the second group, asymmetric information should be reduced for all borrowing operations. Although data may be noisy in group 2 because of the financial distress situation and the low initial number of firms, our results (Table 6) are quite convincing.

The empirical analysis shows that when a bank is present in the equity capital of a firm, the firm's investments exhibit a lower sensitivity to cash flow. In group 1, investment is sensitive to cash flow, and this sensitivity increases in the second period. This result is robust because Tobin's $Q$ coefficient is significant. In group 2, cash flow has no significant influence on investment, regardless of the estimation period. As in the previous classification schemes, these results confirm that the higher the cash flow coefficient is, the tighter the financing constraints are. 
Table 6: Impact of bank ownership structure

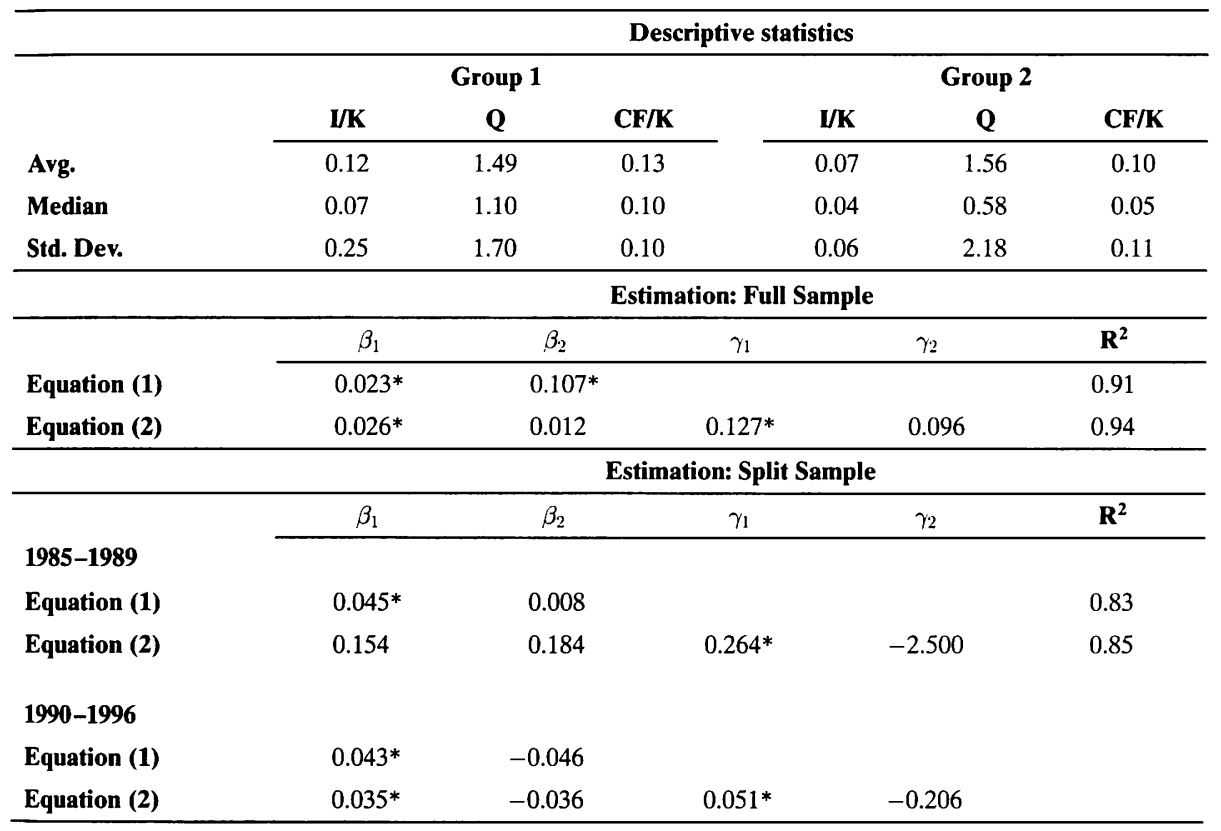

Notes: Firms are first separated between those that do not have a bank as an important shareholder (group 1, 50 firms) and those that do (group 2, 3 firms), with 5 firms changing groups over the sample period. Avg., Med., Std. denote, respectively, average, median and standard deviation. $\mathrm{R}^{2}$ stands for adjusted R-square. A star $\left(^{*}\right)$ denotes statistical significance at the $5 \%$ level.

\subsection{All criteria}

Finally, firms are separated in three groups. In the first group, there are firms that have neither a bank as an important shareholder nor non-traded stocks; in the second, there are firms with non-traded registered shares and in group 3, there are firms that have an important bank shareholder.

Results are presented in Table 7. This table summarizes the main findings of this paper: $i$ ) investments of firms with an important banking shareholder have a low sensitivity to cash flow; ii) when the business cycle is taken into account, firms exhibit heterogeneous sensitivities to cash flow in the recession period and homogeneous sensitivities in the expansion period; $i i$ ) when the sample is split, the investment level of firms that do not trade their registered shares (group 2) exhibit a lower sensitivity to cash flow than firms that trade their registered shares and do not have an important bank shareholder (group 1), but, similar to the conclusions reached by KAPLAN and ZiNGaLEs (1997), this result is due to the non-significance of Tobin's $Q$ coefficient for group 2 firms and noth- 
ing can be said about financial constraints; $i v$ ) the empirical findings suggest that the function linking investment-cash flow sensitivities and the intensity of financial constraints is monotonic increasing in the recession period.

Table 7: Impact of ownership structure

\begin{tabular}{|c|c|c|c|c|c|c|c|c|c|}
\hline & \multicolumn{9}{|c|}{ Descriptive Statistics } \\
\hline & \multicolumn{3}{|c|}{ Group 1} & \multicolumn{3}{|c|}{ Group 2} & \multicolumn{3}{|c|}{ Group 3} \\
\hline & $\mathbf{I} / \mathbf{K}$ & $\mathbf{Q}$ & CF/K & $\mathbf{I} / \mathbf{K}$ & $\mathbf{Q}$ & CF/K & $\mathbf{I} / \mathbf{K}$ & $\mathbf{Q}$ & CF/K \\
\hline Avg. & 0.11 & 1.13 & 0.11 & 0.14 & 2.25 & 0.15 & 0.07 & 1.56 & 0.10 \\
\hline Median & 0.07 & 1.04 & 0.10 & 0.07 & 1.26 & 0.11 & 0.04 & 0.58 & 0.05 \\
\hline \multirow[t]{3}{*}{ Std. Dev. } & 0.25 & 0.62 & 0.08 & 0.24 & 2.79 & 0.14 & 0.06 & 2.18 & 0.11 \\
\hline & \multicolumn{9}{|c|}{ Estimation: Full Sample } \\
\hline & $\beta_{1}$ & $\beta_{2}$ & $\overrightarrow{\beta_{3}}$ & $\gamma_{1}$ & $\gamma_{2}$ & $\gamma_{3}$ & $\mathbf{R}^{2}$ & & \\
\hline Eq. (1) & $0.028^{*}$ & $0.021^{*}$ & $0.119^{*}$ & & & & 0.75 & & \\
\hline \multirow[t]{3}{*}{ Eq. (2) } & $0.026^{*}$ & 0.014 & 0.063 & 0.033 & $0.196^{*}$ & 0.139 & 0.81 & & \\
\hline & \multicolumn{9}{|c|}{ Estimation: Split Sample } \\
\hline & $\beta_{1}$ & $\beta_{2}$ & $\beta_{3}$ & $\gamma_{1}$ & $\gamma_{2}$ & $\gamma_{3}$ & $\mathbf{R}^{2}$ & & \\
\hline \multicolumn{10}{|l|}{ 1985-1989 } \\
\hline Eq. (1) & $0.035^{*}$ & $0.045^{*}$ & 0.013 & & & & 0.78 & & \\
\hline Eq. (2) & -0.003 & 0.022 & 0.180 & $0.590^{*}$ & $0.308^{*}$ & -1.88 & 0.81 & & \\
\hline \multicolumn{10}{|l|}{ 1990-1996 } \\
\hline Eq. (1) & $0.034^{*}$ & $0.045^{*}$ & -0.042 & & & & & & \\
\hline Eq. (2) & $0.042 *$ & $0.039^{*}$ & -0.026 & 0.026 & $0.220^{*}$ & 0.117 & & & \\
\hline
\end{tabular}

Notes: Firms are first separated between those that have no bank as an important shareholder and trade all their shares (group 1, 33 firms), those that no bank as an important shareholder and do not trade all their shares (group 2, 14 firms), and those who have a bank as an important shareholder (group 3, 3 firms), with 8 firms changing groups over the sample period. Avg., Med., Std. denote, respectively, average, median and standard deviation. $\mathrm{R}^{2}$ stands for adjusted $\mathrm{R}$-square. A star $\left(^{*}\right)$ denotes statistical significance at the $5 \%$ level.

\subsection{Alternative Measure of Investment Opportunities}

The empirical literature on investment has stressed the importance of production as an explanatory variable for investment opportunities. The theoretical justification can be found in Keynesian models, where firms are constrained by a maximal level of sales and therefore output is the only variable that explains investment levels. Some authors have also found that production was a better proxy for investment opportunities than the average $Q$.

In order to check the robustness of the results, we performed the same experiments using sales as an alternative proxy for investment opportunities. Although sales perform 
slightly better than Tobin's $Q$ in terms of significance, we obtained similar results and reach similar conclusions: ${ }^{12}$

- Investment by firms that are more likely to be financially constrained is more sensitive to cash flow;

- When firms are classified in three groups, we obtain a monotonically increasing function linking investment-cash flow to the intensity of financial constraints;

- In the boom period, investment-cash flow sensitivities are homogeneous.

\section{CONCLUSIONS}

In this study, several models have been applied to the Swiss market to determine the appropriate explanatory variables for investment. The $Q$ theory, despite the problem of mismeasurement, explains on average more than $70 \%$ of investment behavior. With the inclusion of cash flow, we reach more than $90 \%$. This is remarkable in comparison to similar studies and suggests that our conclusions are valid.

We separate firms with more asymmetric information from firms with less asymmetric information. When the full sample is used, results similar to those found by FAZZARI et al. (1988) are obtained. When the business cycle is taken into account, the same result is obtained in the recession period. In the boom period, firms exhibit similar investmentcash flow sensitivities. For certain classifications schemes, results are the same as those of KAPLAN and ZiNGALES (1997), but the values are not significant, leading us to conclude that sensitivities are homogeneous. As asymmetric information is the leading theoretical explanation for the wedge between internal and external financial costs, it is difficult to resist the conclusion that the higher the cash flow-investment sensitivities, the higher the financial constraints. This paper suggests that, in contrast to the claim of KAPLAN and ZINGALES (1997), investment-cash flow sensitivities provide useful measures of financial constraints.

An interesting extension would be to model explicitly internal financing sources and more particularly balance sheet restructurings. A first step in this direction can be found in LAMONT (1997). In his study, the author took large oil companies that also have nonoil sectors and studies the influence of cash flow-investment sensitivities in the two sectors. He found that a reduction of cash flow in the oil segments (due to the 1986 oil price decrease) decreases investment levels in non-oil segments and that there are cross-subsidies among sectors.

12. Another advantage of using sales is that our sample increases from 58 to 83 firms. Detailed results and Tables are available from the authors. 


\section{APPENDIX A: LIST AND CLASSIFICATION OF FIRMS}

\begin{tabular}{|c|c|c|c|c|c|c|c|}
\hline Firm & Period & Clas. 1 & Clas. 2 & Clas. 3 & Clas. 4 & Clas. 5 & \\
\hline ABB & $84-96$ & 1 & 1 & 1 & 1 & 1 & $*$ \\
\hline Affichage & $84-96$ & 1 & 1 & 1 & 1 & 1 & $*$ \\
\hline \multirow[t]{2}{*}{ Agie } & $84-93$ & 2 & 2 & 3 & 2 & 3 & \\
\hline & $94-96$ & 1 & 1 & 1 & 2 & 3 & \\
\hline Alussuisse-Lonza & $84-96$ & 1 & 1 & 1 & 1 & 1 & \\
\hline Arbonia-Foster & $86-96$ & 2 & 2 & 3 & 1 & 2 & \\
\hline Ares-Serono & $85-96$ & 1 & 2 & 2 & 1 & 1 & $*$ \\
\hline Atel & $86-96$ & 1 & 2 & 2 & 1 & 1 & \\
\hline Attisholz & $84-96$ & 1 & 1 & 1 & 1 & 1 & \\
\hline \multirow[t]{2}{*}{ Biber } & $84-93$ & 1 & 1 & 1 & 1 & 1 & \\
\hline & $94-96$ & 1 & 1 & 1 & 2 & 3 & \\
\hline Bobst & $84-96$ & 1 & 1 & 1 & 1 & 1 & \\
\hline Bucher & $84-95$ & 2 & 2 & 3 & 1 & 2 & \\
\hline \multirow[t]{2}{*}{ Calida } & $85-95$ & 2 & 2 & 3 & 1 & 2 & \\
\hline & 96 & 1 & 2 & 2 & 1 & 1 & \\
\hline \multirow[t]{2}{*}{ Canon/Walter-Rentsch } & $84-95$ & 2 & 2 & 3 & 1 & 2 & \\
\hline & 96 & 1 & 2 & 2 & 1 & 1 & \\
\hline Cementia & $84-96$ & 1 & 2 & 2 & 1 & 1 & \\
\hline Ciba & $84-94$ & 1 & 1 & 1 & 1 & 1 & \\
\hline Cortaillod & $85-95$ & 1 & 2 & 2 & 1 & 1 & \\
\hline Daetwyler & $84-96$ & 2 & 2 & 3 & 1 & 2 & \\
\hline \multirow[t]{2}{*}{ Elco-Looser } & $84-92$ & 2 & 2 & 3 & 1 & 2 & \\
\hline & $93-94$ & 1 & 1 & 1 & 1 & 1 & \\
\hline EMS-Chiinie & $84-96$ & 2 & 2 & 3 & 1 & 2 & \\
\hline Feldschlossen & $84-96$ & 1 & 2 & 2 & 1 & 1 & \\
\hline Forbo & $84-96$ & 1 & 1 & 1 & 1 & 1 & \\
\hline Fuchs Petrolub & $84-96$ & 1 & 2 & 2 & 1 & 1 & * \\
\hline Galenica & $84-96$ & 1 & 1 & 1 & 1 & 1 & \\
\hline Gavazzi & $84-96$ & 2 & 2 & 3 & 1 & 2 & \\
\hline Georg Fischer & $84-90$ & 1 & 1 & 1 & 1 & 1 & \\
\hline Gurit & $84-96$ & 2 & 2 & 3 & 1 & 2 & $*$ \\
\hline Hero & $84-96$ & 1 & 2 & 2 & 1 & 1 & \\
\hline Hilti & $84-96$ & 2 & 2 & 3 & 1 & 2 & $*$ \\
\hline Holderbank & $84-96$ & 1 & 2 & 2 & 1 & 1 & $*$ \\
\hline Holvis & $84-94$ & 1 & 1 & 1 & 1 & 1 & $*$ \\
\hline \multirow[t]{2}{*}{ Huber \& Suhner } & $84-93$ & 1 & 1 & 1 & 2 & 3 & $*$ \\
\hline & $94-96$ & 1 & 1 & 1 & 1 & 1 & $*$ \\
\hline Immuno & $84-96$ & 2 & 2 & 3 & 1 & 2 & * \\
\hline
\end{tabular}




\begin{tabular}{|c|c|c|c|c|c|c|c|}
\hline Firm & Period & Clas. 1 & Clas. 2 & Clas. 3 & Clas. 4 & Clas. 5 & \\
\hline Industrieholding Chain & $84-96$ & 1 & 1 & 1 & 2 & 3 & \\
\hline Interdiscount & $84-94$ & 2 & 2 & 3 & 1 & 2 & \\
\hline Jacob Suchard & $84-88$ & 2 & 2 & 3 & 1 & 2 & * \\
\hline Jelmoli & $84-96$ & 1 & 2 & 2 & 1 & 1 & \\
\hline Keramik Laufen & $84-96$ & 2 & 2 & 3 & 1 & 2 & \\
\hline Konsum Verein & $84-94$ & 1 & 1 & 1 & 1 & 1 & \\
\hline Kuhne \& Nagel & $90-96$ & 2 & 2 & 3 & 1 & 2 & $*$ \\
\hline Kuoni & $90-96$ & 2 & 2 & 3 & 1 & 2 & \\
\hline Landis \& Gyr & $84-94$ & 1 & 2 & 2 & 1 & 1 & \\
\hline LEM & $88-96$ & 1 & 1 & 1 & 1 & 1 & * \\
\hline Lindt \& Sprungli & $84-96$ & 1 & 2 & 2 & 1 & 1 & \\
\hline Logitech & $88-96$ & 1 & 2 & 2 & 1 & 1 & $*$ \\
\hline Maag & $84-96$ & 1 & 1 & 1 & 1 & 1 & \\
\hline Michelin & $84-96$ & 2 & 2 & 3 & 1 & 2 & $*$ \\
\hline Merck & $84-94$ & 2 & 2 & 3 & 1 & 2 & \\
\hline \multirow[t]{3}{*}{ Mikron } & $84-88$ & 1 & 1 & 1 & 1 & 1 & \\
\hline & $89-94$ & 1 & 1 & 1 & 2 & 3 & \\
\hline & $95-96$ & 1 & 1 & 1 & 1 & 1 & \\
\hline \multirow[t]{3}{*}{ Motor Colombus } & $87-93$ & 1 & 1 & 1 & 2 & 3 & \\
\hline & $94-95$ & 1 & 2 & 2 & 2 & 3 & \\
\hline & 96 & 1 & 1 & 1 & 2 & 3 & \\
\hline \multirow[t]{2}{*}{ Movenpick } & $84-93$ & 1 & 2 & 2 & 2 & 3 & \\
\hline & $94-96$ & 1 & 1 & 1 & 1 & 1 & \\
\hline Nestlé & $84-96$ & 1 & 1 & 1 & 1 & 1 & \\
\hline Nestal & $84-96$ & 2 & 2 & 3 & 1 & 2 & \\
\hline Novartis & $90-96$ & 1 & 1 & 1 & 1 & 1 & $*$ \\
\hline Pelikan & $84-96$ & 2 & 2 & 3 & 1 & 2 & $*$ \\
\hline Phoenix Mecano & $86-96$ & 1 & 1 & 1 & 1 & 1 & $*$ \\
\hline \multirow[t]{2}{*}{ Publicitas } & $88-95$ & 2 & 1 & 1 & 1 & 1 & \\
\hline & 96 & 1 & 1 & 1 & 1 & 1 & \\
\hline Rieter & $84-96$ & 1 & 1 & 1 & 1 & 1 & \\
\hline Richemont & $88-95$ & 2 & 2 & 3 & 1 & 2 & $*$ \\
\hline Roche & $84-96$ & 1 & 2 & 2 & 1 & 1 & $*$ \\
\hline Sandoz & $84-95$ & 1 & 1 & 1 & 1 & 1 & \\
\hline Sarna & $84-96$ & 1 & 1 & 1 & 1 & 1 & \\
\hline Saurer & $89-96$ & 1 & 1 & 1 & 1 & 1 & \\
\hline Schindler & $84-96$ & 1 & 2 & 2 & 1 & 1 & \\
\hline Schlatter & $84-96$ & 1 & 2 & 2 & 1 & 1 & \\
\hline Schweiter & $90-96$ & 1 & 2 & 2 & 1 & 1 & $*$ \\
\hline Scintilla & $84-96$ & 1 & 2 & 2 & 1 & 1 & \\
\hline
\end{tabular}




\begin{tabular}{|c|c|c|c|c|c|c|c|}
\hline Firm & Period & Clas. 1 & Clas. 2 & Clas. 3 & Clas. 4 & Clas. 5 & \\
\hline Siegfried & $84-96$ & 1 & 1 & 1 & 1 & 1 & \\
\hline \multirow[t]{2}{*}{$\mathrm{Sig}$} & $84-90$ & 1 & 1 & 1 & 1 & 1 & \\
\hline & $91-96$ & 1 & 1 & 1 & 1 & 1 & $\cdot$ \\
\hline \multirow[t]{2}{*}{ Sill } & $87-93$ & 1 & 2 & 2 & 1 & 1 & \\
\hline & $94-96$ & 1 & 1 & 1 & 1 & 1 & \\
\hline Sika & $84-96$ & 1 & 2 & 1 & 1 & 1 & \\
\hline SMH & $84-96$ & 1 & 2 & 2 & 1 & 1 & \\
\hline Sirecher \& Schuh & $85-93$ & 1 & 1 & 1 & 1 & 1 & $*$ \\
\hline Sulzer & $84-96$ & 1 & 1 & 1 & 1 & 1 & \\
\hline Swisslog & $91-96$ & 1 & 1 & 1 & 1 & 1 & $*$ \\
\hline \multirow[t]{2}{*}{ Valora/Merkur } & $84-89$ & 1 & 1 & 1 & 1 & 1 & \\
\hline & $90-96$ & 1 & 1 & 1 & 1 & 1 & \\
\hline Vetropack & $84-96$ & 2 & 2 & 3 & 1 & 2 & \\
\hline \multirow[t]{2}{*}{ VonMoos } & $85-95$ & 2 & 2 & 3 & 1 & 2 & \\
\hline & 96 & 1 & 2 & 2 & 2 & 3 & \\
\hline \multirow[t]{2}{*}{ VonRoll } & $84-94$ & 1 & 1 & 1 & 1 & 1 & \\
\hline & $95-96$ & 1 & 2 & 2 & 2 & 3 & \\
\hline LVMH & $84-96$ & 2 & 2 & 3 & 1 & 2 & \\
\hline Zehnder & $84-96$ & 2 & 2 & 3 & 1 & 2 & \\
\hline Zdllweger Luwa & $87-96$ & 2 & 2 & 3 & 1 & 2 & * \\
\hline Zsdhokke & $88-96$ & 1 & 1 & 1 & 1 & 1 & \\
\hline Zucrdher Ziegelin & $84-96$ & 2 & 2 & 3 & 1 & 2 & \\
\hline
\end{tabular}

Notes: firms noted by * are used only in the estimation where sales is used as a proxy for investmen opportunities. Other firms are used in both experiments. "clas." means classification scheme. The digil gives the group. The classification schemes can be summarized as follows:

Classification 1

Group 1: all stocks are publicly traded.

Group 2: all stocks are not publicly traded.

Classification 2

Group 1: no major shareholder.

Group 2: presence of a major shareholder.

Classification 3

Group 1: no major shareholder; all stocks are publicly traded.

Group 2: presence of a major shareholder; all shares are publicly traded.

Group 3: presence of a major shareholder; all shares are not publicly traded.

Classification 4

Group 1: no important bank shareholder.

Group 2: presence of an important bank shareholder.

\section{Classification 5}

Group 1: no important bank shareholder; all shares are publicly traded.

Group 2: no important bank shareholder; all shares are not publicly traded.

Group 3: important bank shareholder; all stocks are publicly traded. 


\section{APPENDIX B: VARIABLES DEFINITIONS}

In this appendix, we describe the different variables we are using and how they were computed.

- Investment (I) is defined as the difference between the capital stock in time $t+1$ and the capital stock in time $t$ corrected for depreciation. This definition is taken from the Swiss stock guide.

- Cash flow (CE) is also directly taken from the Swiss stock guide and has the usual definition.

- We use the fire insurance value of capital as a proxy for the replacement cost of capital $(\mathrm{K})$. In the balance sheet, the value of capital is given by the purchasing value of capital corrected for depreciation. In principle, this value represents the replacement cost of capital. Unfortunately, because of fiscal particularities, ${ }^{13}$ Swiss firms use a higher rate of depreciation than the one that is economically justified. Therefore, the capital value given in the balance sheet is usually underestimated. To get rid of this problem, we use as a proxy the fire insurance value of capital. As firms do not have any incentive to insure a non-economically justified value, the fire insurance value represents a good proxy for the replacement cost of capital.

- Net working capital (WC) is computed as the difference between short-term assets and short-term liabilities.

To compute Tobin's $Q(Q)$, we follow Salinger-Summers (1983):

$$
Q_{i t}=\frac{V_{i t}+D_{i t}-S_{i t}}{K_{i t}}
$$

where $V, D$ and $S$ represent, respectively, the market value of shares, of the debt and of the inventories.

All the corresponding time series are directly taken from the Swiss Stock Guide. $V$ is computed as the average of December market value of the firm. For firms with nontraded stocks, we assume that the non-traded stocks have the same price as the traded ones. $D$ is the book value of debt. As most of the debt is generally composed of bank loans, no market price exists; thus our choice. Taxes are not taken into account because the tax system depends on local laws and on agreements with local and canton authorities. It is, therefore, impossible to take taxes into account because the effective tax rates are private information. Using an instrumental variable estimation method should prevent biased results.

13. Swiss fiscal law gives maximal rates of depreciation for different types of capital goods. Usually, these rates are above the economically justified depreciation rates. Therefore, firms use these rates in order to lower their profits and, thus, their tax bills. This resulted in the creation of "hidden reserves". 


\section{REFERENCES}

Admati, A., P. Pfleiderer. and J. Zechner (1994), "Large shareholder activism, risk sharing, and financial market equilibrium", Journal of Political Economy, 102. p. 1097-1130.

Barclay, M. and C. Holderness (1989), "Private benefits from control of public corporations", Journal of Financial Economics, 25, p. 371-395.

BARRAN, F. (1994), "Credit market imperfections, financial structure and economic activity: an overview of empirical findings", Mimeo, Université Catholique de Louvain.

Berger, A. N. and G. F. Udell (1995), "Relationship Lending and Lines of Credit in Small Firm Finance", Journal of Business, 68, p. 351-381.

Bernanke, B., M. Gertler and S. Gilchrist (1996), "The financial accelerator and the flight to quality", The Review of Economics and Statistics, 78, p. 1-15.

Brainard, W. C. and J. Tobin (1977), "Asset market and the cost of capital", in: B. Balassa and R. Nelson (eds.), Economic Progress, Private Values and Public Policy: Es. says in Honor of William Fellner, Amsterdam, p. 235-262.

CALEM, P.S. and J. A. Rızzo (1995), "Financing constraints and investment: new evidence from hospital industry data", Journal of Money, Credit, and Banking, 27, p. 1002-1014.

Chirinko, R.S. and H. Schaller (1995), "Why does liquidity matter in investment equations?", Journal of Money, Credit and Banking, 27, p. 527-548.

Denis, D.J., D.K. Denis and A. Sarin (1994), "The information content of dividend changes: cash flows signaling, over-investment and dividend clienteles", Journal of Financial and Quantitative Analysis, 29, p. 567-587.

Dewatripont, M. and J. Tirole (1994), "A theory of debt and equity: diversity of securities and manager-shareholder congruence”, Quarterly Journal of Economics, 109, p. $1027-54$.

Fazzari, S. M., G. R. Hubbard and B.C. Peterson (1988), "Financing Constraints and Corporate Investment", Brookings Papers on Economic Activity, p. 141-195.

Fazzari, S. M., G.R. Hubbard and B.C. Peterson (1993), "Working capital and fixed investment: new evidence on financing constraints", Rand Journal of Economics, 24, p. 328-341.

Fazzari, S.M., G. R. Hubbard and B.C. Peterson (1996), "Financing constraints and corporate investment: response to Kaplan and Zingales", NBER Working Paper no. 5462 .

Gertler, M. (1988), "Financial Structure and Aggregate Economic Activity: An Overview", Journal of Money Credit and Banking, 20, p. 559-588.

Gilchrist, S. and C.P. Himmelberg (1995), "Evidence on the role of cash flows in reduced-form investment equations", Journal of Monetary Economics, 36, p. 541-572.

Gorton, G. and F. A. Schmid (1996), "Universal banking and the performance of German firms", Wharton Working Paper 96-11.

Greenbaum, S., G. Kanatas and I. Venezia (1989), "Equilibrium loan pricing under the bank-client relationship", Journal of Banking and Finance, p. 221-235. 
HoRner, M.R. (1988), "The value of the corporate voting right: evidence from Switzerland", Journal of Banking and Finance, 12, p. 69-83.

Hoshi, T., A. Kashyap and D. Scharfstein (1991), "Corporate structure, liquidity, and investment: evidence from Japanese industrial groups", Quarterly Journal of Economics, 106, p. 33-60.

Hubbard, G.R. (1998), "Capital-market imperfections and investment", Journal of Economic Literature, 36, p. 193-225.

Hubbard, G. R., A.K. Kashyap and T.M. Whited (1995), "Internal finance and firm investment", Journal of Money, Credit, and Banking, 27, p. 683-701.

Jensen, M. and W. Meckling (1976), "Theory of the firm: managerial behavior, agency costs, and ownership structure", Journal of Financial Economics, 3, p. 305-360.

KadapakKam, P.R., P.C. Kumar and L.A. Riddick (1998), "The impact of cash flows and firm size on investment: the international evidence", Journal of Banking \& Finance, 22, p. 293-320.

Kaplan, S.N. and L. Zingales (1997), "Do investment-cash flows sensitivities provide useful measures of financing constraints?", Quarterly Journal of Economics, 20, p. $169-215$.

KAPLAN, S.N. and L. Zingales (1995), "Do financing constraints explain why investment is correlated with cash flow", NBER Working Paper no 5627.

Kathuria, R. and D. Mueller (1995), "Investment and cash flow: asymmetric information or managerial discretion?", Empirica, 22, p. 211-234.

La Porta, R., F. Lopez-de-Silanes and A. Shleifer (1999), "Corporate ownership around the world", Journal of Finance,54, p. 471-517.

Lamont, O. (1997), "Cash flows and investment: evidence from internal capital markets”, Journal of Finance, 52, p. 83-109.

Loderer, C. and A. JAcoBs (1995), “The Nestlé crash”, Journal of Financial Economics, 37, p. 315-339.

Modigliani, F. and M. Miller (1958), "The cost of capital, corporation finance and the theory of investment", American Economic Review, 48, p. 261-297.

MYERS, S. (1977), “The determinants of corporate borrowing”, Journal of Financial Economics, 5, p. 147-175.

Myers, S. and N. Majluf (1984), "Corporate financing and investment decisions when firms have information that investors do not have", Journal of Financial Economics, 13, p. 187-221.

Poterba, J. (1988), “Comment on: Fazzari, Hubbard and Peterson”, Brookings Papers on Economic Activity, p. 200-204.

RaJAN, R. (1992), "A theory of the costs and benefits of universal banking”, Center for Research in Security Prices Working Paper No. 346, University of Chicago, Chicago, IL.

SAlinger, M.A. and L.H. Summers (1983), "Tax reform and corporate investment: a microeconometric simulation study”, in: M. Feldstein (ed.), Behavioral Simulation Methods in Tax Policy Analysis, p. 247-281. 
Sharpe, S. A. (1990), "Asymmetric information, bank lending and implicit contracts: a stylized model of customer relationships", Journal of Finance, 45, p. 1069-1087.

SHLEIFER, A. and R. A. VISHNy (1997), "A survey of corporate governance", Journal of Finance, 52, p. 737-783

Schwiete, M. and J. Weigand (1997), "The corporate financial behavior of German firms", working paper, Friedrich Alexander Universität Erlangen/Nürnberg.

Stiglitz, J. and A. Weiss (1981), "Credit rationing in markets with imperfect information", The American Economic Review, p. 393-410.

Stulz, R. (2000), "Does financial structure matter for economic growth? a corporate finance perspective", Ohio State University working paper, January.

STUlz, R. and W. WASSERFALLEN (1995), "Foreign equity investment restrictions, capital flight, and shareholder wealth maximization: theory and evidence", Review of Fi. nancial Studies, 8, p. 1019-1057.

Toвin, J. (1969), "A general equilibrium approach to monetary theory", Journal of Money, Credit, and Banking, 1, p. 15-29.

VoGt, S.C. (1994), "The cash flow/investment relationship: evidence from US manufacturing firms", Financial Management, 23, p. 3-20.

White, H. (1984), Asymptotic theory for econometricians, New York.

Whited, T.M. (1992), "Debt, liquidity constraints, and corporate investment: evidence from panel data", Journal of Finance, 47, p. 1425-1460.

ZiNGALES, L. (1994), "The value of the voting right: a study of the Milan stock exchange experience”, Review of Financial Studies, 7, p. 125-148.

\section{SUMMARY}

We study the empirical link that exists between investment-cash flow sensitivities and financial constraints in the Swiss financial market. We follow the standard approach introduced by Fazarri, Hubbard and Peterson (1988), but improve it by using a dynamic classification of firms, a new estimation procedure, while paying particular attention to information asymmetry indicators. We observe that investment-cash flow sensitivities are homogeneous among firms during boom periods, as in KAPLAN and Zingales (1995), but heterogeneous during recession periods. The link between investment-cash flow sensitivities and the intensity of financing constraints is monotonically increasing, as in Fazarri, Hubbard and Peterson (1988).

\section{ZUSAMMENFASSUNG}

Wir studieren die empirischen Verknüpfungen zwischen "investment-cash flow" Empfindlichkeiten und finanziellen Beschränkungen im Schweizer Finanzmarkt. Wir verwenden den Standardansatz, eingeführt von Fazarri, Hubbard und Peterson (1998), 
verbessern ihn jedoch durch die Benutzung einer dynamischen Klassifizierung von Firmen, eines neuen Einschätzungsverfahrens und indem wir asymetrischen Indikatoren spezielle Aufmerksamkeit schenken. Wir stellen fest, dass die "Investement-cash flow"-Schwachstellen in allen Firmen während des Booms homogen sind, wie auch in Kaplan und Zingales (1995), während der Rezession aber heterogen sind. Die Verbindung zwischen "Investment-cash flow"-Schwachstellen, der Intensität und den Finanzierungsengpässen nimmt stetig zu, wie in Fazarri, Hubbard und Peterson (1998).

\section{RÉSUMÉ}

Nous étudions le lien empirique entre les sensibilités investissement/cash-flow et les contraintes financières sur le marché suisse. Nous suivons l'approche standard proposée par Fazarri, Hubbard et Peterson (1988), mais l'améliorons en utilisant une classification dynamique des entreprises, une nouvelle procédure d'estimation, et en portant une attention particulière aux indicateurs d'asymétrie d'information. Nous observons des sensibilités homogènes entre investissement et cash-flow lors de périodes d'expansion économique tout comme chez KAPLAN et Zingales (1995), mais hétérogènes durant les périodes de récession. Le lien entre les sensibilités investissement/cash-flow et les contraintes financières est croissant monotone, tout comme chez FAZARRI, HUBBARD et Peterson (1988). 